\title{
Universal definition of perioperative bleeding in cardiac surgery adults and association with mortality in a Mexican Cardiovascular Critical Care Unit
}

\section{Definición universal de sangrado perioperatorio en cirugía cardiaca adultos y asociación con mortalidad en una Unidad de Terapia Intensiva Cardiovascular de México}

\author{
Damián Gutiérrez-Zárate ${ }^{1,2 *}$, Eduardo Bucio-Reta ${ }^{2}$, and Francisco M. Baranda-Tovar ${ }^{3}$ \\ ${ }^{1}$ Department of Intensive Care Unit, Angeles Tijuana Hospital, Baja California; ${ }^{2}$ Department of Cardiovascular Critical Care Unit, National Institute \\ of Cardiology Ignacio Chávez, Mexico City; ${ }^{3}$ Direction of Surgical Medical Specialties, National Institute of Cardiology Ignacio Chávez, Mexico City, \\ Mexico
}

\begin{abstract}
Background: Bleeding as a complication is associated with poorer results in cardiac surgery. There is increasing evidence that the use of blood products is an independent factor of increased morbidity, mortality, and hospital costs. Dyke et al. established the universal definition of perioperative bleeding (UDPB). This classification is more precise defining mortality in relation to the degree of bleeding. Methods: $A$ descriptive and analytical retrospective study of a database of patients underwent cardiac surgery from January 1, 2016, to December 31, 2017, was performed. The primary objective of the study was to look at mortality associated with the degree of bleeding using the UDPB. Results: A total of 918 patients who went to cardiac surgery were obtained. Most of the population was classified as insignificant bleeding class ( $n=666,72.9 \%)$, and for massive bleeding the lowest proportion $(n=25,2.7 \%)$. For the primary outcome of 30-day mortality, a significant difference was found between the groups, observing that it increased to a higher degree of bleeding. This was corroborated by multivariate logistic regression analysis that was adjusted to EuroScore II and cardiopulmonary bypass (CPB) duration, finding an independent association of the bleeding class with 30-day mortality (OR, 95\%, 5.82 [2.22-15.26], $p=0.0001)$. Conclusions: We found that the higher the degree in UDPB was associated with higher mortality independently to EuroScore II and CPB duration for adult patients undergoing cardiac surgery.
\end{abstract}

Key words: Cardiac surgery. Bleeding. Blood transfusion.

\section{Resumen}

Antecedentes: El sangrado como complicación está asociado a peores resultados en cirugía cardiaca. Existe una evidencia cada vez mayor que la transfusión de productos sanguíneos por si solo es un factor independiente de incremento en la morbilidad, mortalidad, y costos hospitalarios. Dyke y colaboradores establecieron la definición universal de sangrado perioperatorio. Esta clasificación es más precisa en definir mortalidad en relación con el grado de sangrado. Material y métodos: Se

Correspondence:

*Damián Gutiérrez-Zárate

E-mail: dr.guzda@gmail.com license (http://creativecommons.org/licenses/by-nc-nd/4.0/).

Date of reception: 13-04-2019

Date of acceptance: 05-08-2020 DOI: 10.24875/ACM.19000188
Available online: $23-12-2020$ Arch Cardiol Mex. 2020;90(4):373-378 www.archivoscardiologia.com 
realizo un estudio descriptivo y analítico de tipo retrospectivo de una base de datos de pacientes que fueron a cirugía cardiaca del 1 enero del 2016 al 31 de diciembre del 2017. El objetivo primario del estudio fue observar la mortalidad asociada con el grado de sangrado utilizando la definición universal de sangrado perioperatorio. Resultados: Se obtuvieron un total de 918 pacientes que fueron a cirugía cardiaca. La mayor parte de la población fue clasificada como clase de sangrado insignificante $(n=666,72.9 \%)$, y para sangrado masivo la menor proporción $(n=25,2.7 \%)$. En el desenlace primario de mortalidad a 30 días se encontró una diferencia significativa entre los grupos, observando que aumentada a mayor clase de sangrado. Esto fue corroborado mediante un análisis multivariado regresión logística que fue ajustado a con EuroScore Il y el tiempo de bomba de circulación extracorpórea, encontrando una asociación independiente de la clase de sangrado con mortalidad a 30 días (OR, 95\%, 5.82 [2.22-15.26], $p=0.0001$ ). Conclusiones: Encontramos que cuanto mayor era el grado en la UDPB se asociaba con una mayor mortalidad independientemente de EuroScore Il y la duración del bypass cardiopulmonar para pacientes adultos sometidos a cirugía cardíaca.

Palabras clave: Cirugía cardíaca. Sangrado. Transfusión de sangre.

\section{Introduction}

Bleeding is an important issue in cardiac surgery, about $20 \%$ of all blood products are transfused in this scenario around the world ${ }^{1}$. Bleeding as a complication is associated with poorer results in cardiac surgery. In a retrospective analysis that included 1188 cardiac surgery patients, the presence of excessive post-operative bleeding was associated with an increase incidence of surgical re-exploration $(\mathrm{OR}=103.7,95 \% \mathrm{Cl}=45.6$ 235.4, $\mathrm{p}<0.0001$ ), post-operative stroke $(\mathrm{OR}=3.3$, $95 \% \mathrm{Cl}=1.6-7-0, p=0.003)$, mechanical ventilation for more than $24 \mathrm{~h}(\mathrm{OR}=3.4,95 \% \mathrm{Cl}=1.8-6.4, \mathrm{p}=0.0002)$, stay in the intensive care unit (ICU) for more than $72 \mathrm{~h}$ $(\mathrm{OR}=1.4,95 \% \mathrm{Cl}=1.2-3.2, \mathrm{p}<0.0001)$, and increase mortality $(\mathrm{OR}=2.9,95 \% \mathrm{Cl}=2.9-3.0, \mathrm{p}<0.001)^{2}$. Therefore, excessive post-operative bleeding is associated with an increase in hospital costs ${ }^{3}$.

In addition, there is growing evidence that the transfusion of blood products is an independent factor of increase morbidity, mortality, and hospital costs ${ }^{4,5}$.

Post-operative bleeding has been established as an important outcome measure in clinical practice and clinical trials. Despite having precise definitions for other complications in cardiac surgery, there is no standardized definition for post-operative bleeding, making difficult to interpret clinical trials and evaluate the management of blood products. We propose the implementation of the universal definition of perioperative bleeding (UDPB) in adult cardiac surgery to standardize nomenclature, improve outcome definitions, and be useful in future clinical trials.

\section{Materials and methods}

We conducted a retrospective descriptive and analytical study of one hospital. The data were obtained from a database of the cardiovascular ICU of the National Institute of Cardiology Ignacio Chavez in Mexico City. All adult patients $\geq 18$ years old who underwent cardiac surgery from January 1, 2016, to December 31, 2017, were included in the study. Congenital cardiac surgery patients were excluded from the study. The information included in the database was supplemented with information obtained from the files if necessary. The primary objective of the study was to look at mortality associated with the degree of bleeding according to the classification of the UDPB (Table 1). Secondary objectives were to determine whether a greater degree of bleeding was related to an increase stay in the ICU, an increase in hospital stay, and increase events of stroke and acute kidney injury (AKI). The study was approved by the local ethics committee with a waiver of written informed consent.

\section{Statistical analysis}

Continuous variables were represented with medians (interquartile ranges) and for categorical variables number (n) and percentages (\%) were shown. Subsequently, patients were divided into five different groups according to the degree of bleeding using the UDPB. For comparisons of continuous variables Mann-Whitney U-test was used, and Fisher exact test for categorical variables. For those variables with statistical significance ( $\alpha$ value $\leq 0.1$ ) a multivariate logistic regression analysis was made, to determine if the degree of bleeding is independently associated with 30-day mortality. Crude mortality by class of bleeding was adjusted to cardiopulmonary bypass (CPB) duration and EuroScore II, which were the variables that were found with significance in the multimodal regression analysis. 
Table 1. Universal definition for perioperative bleeding in adult cardiac surgery

\begin{tabular}{|l|l|c|c|c|c|c|c|c|c|}
\hline \multicolumn{7}{|c|}{ Bleeding categories according to the UDPB in adult cardiac surgery } \\
\hline $\begin{array}{l}\text { Bleeding } \\
\text { definition }\end{array}$ & $\begin{array}{l}\text { Sternal } \\
\text { closure } \\
\text { delayed }\end{array}$ & $\begin{array}{c}\text { Post-operative chest } \\
\text { tube blood los within } \\
\text { 12 h (mL) }\end{array}$ & $\begin{array}{c}\text { PRBC } \\
\text { (units) }\end{array}$ & $\begin{array}{c}\text { FFC } \\
\text { (units) }\end{array}$ & $\begin{array}{c}\text { PLT } \\
\text { (units) }\end{array}$ & Cryoprecipitate & PCCs & rFVlla & $\begin{array}{c}\text { Re-exploration/ } \\
\text { tamponade }\end{array}$ \\
\hline $\begin{array}{l}\text { Class 0 } \\
\text { (Insignificant) }\end{array}$ & No & $<600$ & 0 & 0 & 0 & No & No & No & No \\
\hline $\begin{array}{l}\text { Class 1 } \\
\text { (Mild) }\end{array}$ & No & $601-800$ & 1 & 0 & 0 & No & No & No & No \\
\hline $\begin{array}{l}\text { Class 2 } \\
\text { (Moderate) }\end{array}$ & No & $801-1000$ & $2-4$ & $2-4$ & Yes & Yes & Yes & Yes & Yes \\
\hline $\begin{array}{l}\text { Class 3 } \\
\text { (Severe) }\end{array}$ & Yes & $1001-2000$ & $5-10$ & $5-10$ & N/A & N/A & N/A & No \\
\hline $\begin{array}{l}\text { Class 4 } \\
\text { (Massive) }\end{array}$ & N/A & $>2000$ & $>10$ & $>10$ & N/A & N/A & N/A & Yes \\
\hline
\end{tabular}

UDPB: universal definition for perioperative bleeding; PRBC: packed red blood cells; FFP: fresh frozen plasma; PLT: platelet concentrates; PCCs: prothrombin complex concentrates; rFVIla: recombinant activated factor VII; N/A: not applicable. The number of PRBCs used should only be considered in the UDPB when accompanied by other signs of perioperative bleeding. If different categories indicate mixed definitions of bleeding, the worst definition applies.

\section{Results}

A total of 918 patients were obtained. The median age was 59 years, with a proportion of women of $42 \%$. About $21.4 \%$ of patients previously used platelet antiaggregant. The highest percentage of surgeries performed in our hospital was valvular type (69.9\%). About $32 \%$ of the surgeries were an emergency intervention. The overall mortality was $8.1 \%$. Complications for stroke were found in $1 \%$ and AKI in $7.8 \%$ of the patients. Most of the population was classified as insignificant bleeding class ( $n=666,72.9 \%$ ), and for massive bleeding the lowest proportion ( $n=25,2.7 \%$ ) (Table 2).

In the comparison by groups defined by the class of bleeding, significant differences were found between the CBP and EuroScore II, both being higher in Class 4 compared to the rest. A significant difference was observed in the number of events of stroke and AKI, being more frequent in Class 4 (Table 3 ).

In the primary outcome of 30-day mortality, a significant difference was found between the groups, observing that it increased to a higher class of bleeding. This was corroborated by a multivariate logistic regression analysis that was adjusted to EuroScore II and CPB duration, finding an independent association of the bleeding with 30-day mortality (OR, 95\%, 5.82 [2.2215.26], $p=0.0001$ ) (Table 4). Subsequently, an adjustment of the mortality by groups was made, which is shown in figure 1.

\section{Discussion}

Excessive bleeding after cardiac surgery is a complex clinical problem despite significant advances in surgical techniques, anesthetic management, and critical care. It is generally accepted is better to avoid the use of blood products as much as possible; however, all cardiac surgery patients are at risk of bleeding and it remains unclear the threshold when the bleeding becomes clinically significant. The way to answer these questions is through the consensus and application of a more precise definition of bleeding.

Mehran et al. published a consensus to define bleeding and be used in cardiovascular clinical trials, but applicable in the context of acute coronary syndromes ${ }^{6}$. In cardiac surgery, the first studies measure bleeding through post-operative chest tube output, mainly in decision-making to emergency reoperation ${ }^{7-9}$. On the other hand, other studies quantified the degree of bleeding by the number of globular packages transfused ${ }^{10,11}$. However, the transfusion strategy of each center may vary, including the hemoglobin threshold, which a globular package is indicated ${ }^{12}$. Ranucci et al. in a retrospective study of a single center with 16,154 patients defined major bleeding by quantifying the chest tube output and it was associated with higher mortality with a $12 \%$ increase of relative risk of death for each $100 \mathrm{ml}$ of increment in the first $12 \mathrm{~h}$ of postoperative bleeding ${ }^{13}$. Taking this as a basis, Dyke et al. established the concept of UDPB, ranking 5 degrees of bleeding 
Table 2. Patient characteristics

\section{Patient characteristics}

Total patients

918

Demographics

\begin{tabular}{|l|c|}
\hline Age (years) & $59[50-67]$ \\
\hline Sex female & $384(42)$ \\
\hline BMI & $26.7[23.6-28.8]$ \\
\hline
\end{tabular}

\section{Comorbidity}

\begin{tabular}{|l|c|}
\hline High Blood Pressure & $387(42)$ \\
\hline Diabetes mellitus type 2 & $205(22)$ \\
\hline Chronic renal failure & $23(2.5)$ \\
\hline Left ventricular ejection fraction $<50 \%$ & $156(17)$ \\
\hline Preoperative therapy & \\
\hline Aspirin & $155(16.9)$ \\
\hline Clopidogrel & $41(4.5)$ \\
\hline Warfarin & $39(4.2)$ \\
\hline
\end{tabular}

\section{Pre-operative labs}

Hemoglobin, mg/dL

11.7 [10.2-13.1]

Creatinine, $\mathrm{mg} / \mathrm{dL}$

$0.9[0.79-1.10]$

\section{Type of surgery}

Coronary artery bypass graft

$162(17.6)$

Valvular

642 (69.9)

Coronary artery bypass graft + Valvular

78 (8.5)

Aorta

$36(3.9)$

Operation details

Elective surgery

$624(68)$

Emergency surgery

294 (32)

EuroScore II, \%

2 [1.2-4.6]

CPB time, min

120 [97-161]

\section{Class of bleeding}

\begin{tabular}{l|c|}
\hline Class 0 (Insignificant) & $666(72.9)$ \\
\hline Class 1 (Mild) & $75(8.2)$ \\
\hline Class 2 (Moderate) & $70(7.6)$ \\
\hline Class 3 (Severe) & $82(8.9)$ \\
\hline Class 4 (Massive) & $25(2.7)$ \\
\hline Outcomes & \\
\hline 30-day mortality & $74(8.1)$ \\
\hline Stroke & $9(1)$ \\
\hline AKI & $72(7.8)$ \\
\hline ICU length of stay, days & $4[2-5]$ \\
\hline Hospital length of stay, days & $23[13-35]$ \\
\hline
\end{tabular}

BMI: body mass index; LVEF: left ventricular ejection fraction; CABG: coronary artery bypass graft; CPB: cardiopulmonary bypass; AKI: acute kidney injury; ICU: intensive care unit. Data presented as median [interquartile range] for continuous variables and counts (percentages) for categorical variables.

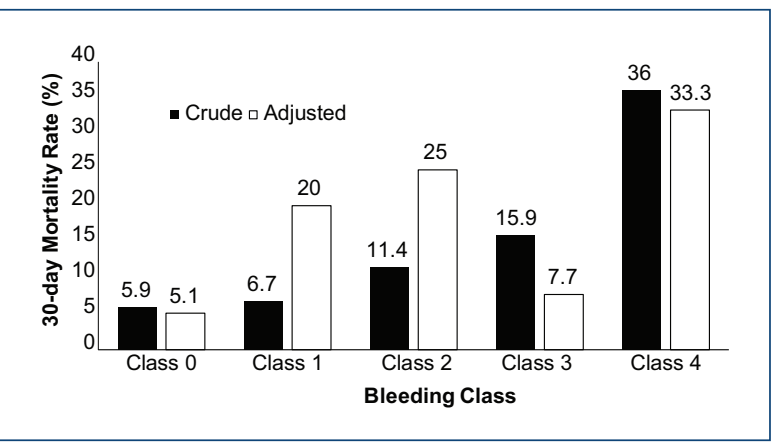

Figure 1. Mortality according to the universal definition for perioperative bleeding classification. Adjusted to EuroScore II and cardiopulmonary bypass duration.

considering the chest tube output, delayed sternal closure, the need for surgical re-exploration, and the use of blood products. This classification proposal is more precise in defining mortality in relation to the degree of bleeding ${ }^{14}$. More recently Colson et al. in a prospective multicenter study define active bleeding as blood loss $>1.5 \mathrm{ml} / \mathrm{kg} / \mathrm{h}$ for 6 consecutive $\mathrm{h}$ in the first $24 \mathrm{~h}$ postoperatively, determining that this definition may be more appropriate for clinical decision-making ${ }^{15}$.

We used the classification proposed by Dyke in our hospital and observed an increase in mortality depending on the degree of bleeding. In the adjustment of mortality with other confounding variables (EuroScore II and CPB duration), the same result was also observed; however, for Classes 1 and 2 the adjusted mortality increases significantly, which can be related to the fact that those two groups have a lower EuroScore II and a lower CPB duration compared to the other groups. The results of our study are like the work of Dyke.

The limitations of this classification and our study are that it does not predict or identify risk factors for bleeding; it does not suggest any treatment or intervention, only attempts to define the degree of perioperative bleeding. We do not compare the UDPB with other classifications suggested in the literature to compare which one is superior to predict worse outcomes or mortality. Another limitation is the retrospective character of the study and only concludes association.

We strongly think the UDPB can be used in cardiac surgery to standardize nomenclature, improve outcome definitions, be useful in future clinical trials, and as a quality measure of care to manage and minimize transfusion. 
Table 3. Outcome in patients for bleeding class

\begin{tabular}{|l|c|c|c|c|c|c|}
\hline \multicolumn{7}{|c|}{ Outcome in patients for bleeding class } \\
\hline & Class 0 & Class 1 & Class 2 & Class 3 & Class 4 & p value \\
\hline CRF & $17(2.6)$ & $1(1.3)$ & $3(4.3)$ & $2(2.4)$ & 0 & 0.74 \\
\hline LVEF < 50\% & $113(17)$ & $9(12)$ & $14(20)$ & $17(20.7)$ & $3(12)$ & 0.55 \\
\hline Aspirin & $116(17.4)$ & $11(14.7)$ & $11(15.7)$ & $14(17.1)$ & $3(12)$ & 0.92 \\
\hline Clopidogrel & $29(4.4)$ & $3(4)$ & $4(5.7)$ & $5(6.1)$ & 0 & 0.73 \\
\hline Warfarin & $28(4.2)$ & $1(1.3)$ & $4(5.7)$ & $4(4.9)$ & $2(8)$ & 0.57 \\
\hline Creatinine, mg/dL & $0.8[0.7-1.2]$ & $0.9[0.8-1.1]$ & $0.9[0.7-1.3]$ & $1[0.8-1.1]$ & $0.9[0.7-1.2]$ & 0.92 \\
\hline Hemoglobin, mg/dL & $10.2[9.7-11.9]$ & $10.1[8.6-12.1]$ & $10.3[9-13.6]$ & $11.8[10-13.6]$ & $12.1[9-14.6]$ & 0.45 \\
\hline EuroScore II, \% & $2.3[1.5-6-8]$ & $1.8[1.1-3.3]$ & $2[1.2-3.4]$ & $2[1.3-6.9]$ & $4[1.8-8.3]$ & 0.003 \\
\hline CPB time, min & $120[100-140]$ & $114[103-150]$ & $117[93-163]$ & $124[97-152]$ & $165[105-223]$ & 0.0001 \\
\hline Emergency surgery & $205(30.7)$ & $21(28)$ & $24(34)$ & $34(41.4)$ & $10(40)$ \\
\hline Stroke & $5(0.8)$ & 0 & 0 & $3(3.7)$ & $1(4)$ \\
\hline AKI & $44(6.6)$ & $6(8)$ & $9(12.9)$ & $8(9.8)$ & $5(20)$ \\
\hline UCI LOS, days & $6[3-8]$ & $4[2-6]$ & $5[3-6]$ & $5[3-11]$ & $4[2-11]$ \\
\hline HLOS, days & $30[23-35]$ & $23[15-29]$ & $29[16-36]$ & $31[15-44]$ & $28[18-36]$ & 0.03 \\
\hline $30-$ day Mortality & $39(5.9)$ & $5(6.7)$ & $8(11.4)$ & $13(15.9)$ & $9(36)$ \\
\hline
\end{tabular}

CRF: chronic renal failure; LVEF: left ventricular ejection fraction; CPB: cardiopulmonary bypass; AKI: acute kidney injury; ICU LOS: intensive care unit length of stay; HLOS: hospital length of stay. Data presented as median [interquartile range] for continuous variables and counts (percentages) for categorical variables.

Table 4. Multivariate regression analysis for 30-day mortality

\begin{tabular}{|l|c|c|}
\hline & OR $(95 \%$ IC) & p value \\
\hline Bleeding class* & $5.82(2.22-15.26)$ & 0.0001 \\
\hline
\end{tabular}

*Adjusted for EuroScore II and cardiopulmonary bypass duration.

More multicenter studies are needed to validate this classification and even establish it as a quality parameter in patient care in cardiac surgery.

\section{Conclusions}

Most cardiac surgical patients have post-operative bleeding without a clinical consequence. But for those with severe to massive bleeding, it can be catastrophic. We found that the higher the degree in UDPB was associated with higher mortality independently in our hospital population. We propose to use the UDPB for improving bleeding management and minimize transfusion in cardiac surgery patients; it can also serve as a measure for institutional quality improvement.

\section{Conflicts of interest}

The authors declare that they have no conflicts of interest.

\section{Ethical disclosures}

Protection of human and animal subjects. The authors declare that no experiments were performed on humans or animals for this study.

Confidentiality of data. The authors declare that no patient data appear in this article.

Right to privacy and informed consent. The authors declare that no patient data appear in this article.

\section{References}

1. Cobain TJ, Vamvakas EC, Wells A, Titlestad K. A survey of the demographics of blood use. Transfus Med. 2007;17:1-15.

2. Christensen MC, Dziewior F, Kempel A, von Heymann C. Increased chest tube drainage is independently associated with adverse outcome after cardiac surgery. J Cardiothorac Vasc Anesth. 2012;46:46-51.

3. Christensen MC, Krapf S, Kempel A, von Heymann C. Costs of excessive postoperative hemorrhage in cardiac surgery. J Thorac Cardiacvasc Surg. 2009;138:687-93.

4. Koch CG, Li L, Duncan Al, Mihaljevic T, Cosgrove DM, Loop FD, et al. Morbidity and mortality risk associated with red blood cell and blood-component transfusion in isolated coronary artery bypass grafting. Crit Care Med. 2006;34:1608-16 
5. Murphy GJ, Reeves BC, Rogers CA, Rizvi SI, Culliford L, Angelini GD. Increased mortality, postoperative morbidity, and cost after red blood cell transfusion in patients having cardiac surgery. Circulation. 2007;116:2544-52.

6. Mehran R, Rao S, Bhatt D, Gibson CM, Caixeta A, Eikelboom J, et al. Standardize bleeding definitions for cardiovascular clinical trials: a consensus report from the bleeding academic research consortium. Circulation. 2011;123:2736-47.

7. Unsworth-White MJ, Herriot A, Valencia O, Poloniecki J, Smith EE, Murday AJ, et al. Resternotomy for bleeding after cardiac operation: a marker for increased morbidity and mortality. Ann Thorac Surg. 1995;59:664-7.

8. Karthik S, Grayson AD, McCarron EE, Pullan DM, Desmond MJ. Reexploration for bleeding after coronary artery bypass surgery: risk factors, outcomes and the time delay. Ann Thorac Surg. 2004;78:837-4.

9. Arévalo-Espinoza S, Izaguirre-Ávila R, Herrera-Alarcón V, Cerón-Díaz U, Bucio-Reta E, Ruiz-Goytortua M. Hemorragia mayor de lo habitual. Arch Cardiol Mex. 2011;81:24-9.

10. Karkouti K, Wijeysundera DN, Yau TM, Beattie WS, Abdelnaem E, McCluskey SA, et al. The independent association of massive blood loss with mortality in cardiac surgery. Transfusion. 2004;44:1453-62.
11. Karkouti K, Wijeysundera DN, Beattie WS, Callum JL, Cheng D, Dupuis JY, et al, Reducing Bleeding in Cardiac Surgery Research Group. Variability and predictability of large-volume red blood cell transfusion in cardiac surgery: a multicenter study. Transfusion. 2007;47: 2081-8.

12. Ranucci M, Aroson S, Dietrich W, Dyke CM, Hofmann A, Karkouti K, et al. Patient blood management during cardiac surgery: do we have enough evidence for clinical practice? J Thorac Cardiacvasc Surg. 2011;142:249.e1-32.

13. Ranucci M, Baryshnikova E, Castelvecchio S, Pelissero G. Major bleeding, transfusions, and anemia: the deadly triad of cardiac surgery. Ann Thorac Surg. 2013;96:478-85

14. Dyke C, Aronson S, Dietrich W, Hofmann A, Karkouti K, Levi M, et al. Universal definition of perioperative bleeding in adult cardiac surgery. $\mathrm{J}$ Thorac Cardiovasc Surg. 2014;147:1458-63.

15. Colson PH, Gaudard P, Fellahi JL, Bertet H, Faucanie M, Amour J, et al. Active bleeding after cardiac surgery: a prospective observational multicenter study. PLoS One. 2016;11:e0162396. 